\title{
Relationship Marketing Orientation and Perceived Organizational Performance of Employees: A Case of Maritime Business Organization
}

İlişkisel Pazarlama Oryantasyonu ve Çalışanların Kurumsal Performans Alg1sı: Deniz İşletmeciliği Örneği

\begin{abstract}
The consumer understanding of the customer-oriented activities of the enterprises primarily depends on the good relations between the employees. Therefore, the relationship between the relationship marketing orientation in the maritime sector, which is gaining more importance in global trade, and the perceived organizational performance (POP) of the employees, has been tried to be determined. Research data $(n=274)$ was collected with a five-point Likert scale electronic survey. After the reliability and validity analysis, the variables were tested in a correlation and multiple regression analysis. As a result, a positive and significant relationship was found between the employees' trust, empathy-based communication and the shared value and their POP. However, only trust and empathy-based communication factors when jointly present were found to be effect on POP.
\end{abstract}

Öz

İsletmelerin müşteri odakh faaliyetlerinin tüketiciler tarafindan anlaşılması öncelikle çalışanlar arasındaki iyi ilişkilere bağlıdır. Bu nedenle küresel ticarette her geçen gün daha da önem kazanan denizcilik sektöründe ilişkisel pazarlama oryantasyonu ile çalışanların kurumsal performans algıları arasındaki ilişki belirlenmeye çalışılmıştır. Araştırma verileri $(n=274)$ Beşli Likert Ölçekli elektronik anket ile toplanmıştır. Değişkenler, güvenirlik ve geçerlik analizinden sonra korelasyon ve çoklu regresyon analizi ile test edilmiştir. Sonuç olarak çalışanların güven, empati temelli iletişim ve değer paylaşımı ile kurumsal performans algıları arasında pozitif yönde anlamlı ilişki olduğu tespit edilmiştir. Ancak sadece güven ve empati temelli iletişim faktörünün birlikte kurumsal performans algısı üzerinde etkili olduğu sonucuna ulaşılmıştır.

Introduction
Maritime is a sector that has an important share in global

Introduction
Maritime is a sector that has an important share in global

\author{
Ali Tehci \\ Assist Prof. Dr., Ordu University, Fatsa \\ Faculty of Marine Sciences, \\ a.tehci@odu.edu.tr, \\ Orcid No: https://orcid.org/0000-0001- \\ 9949-2794
}

\begin{abstract}
Nihan Şenbursa
Assist. Prof. Dr., Ordu University, Fatsa

Faculty of Marine Sciences,

nihansenbursa@odu.edu.tr,

Orcid No: https://orcid.org/0000-00020656-6158
\end{abstract}

\begin{abstract}
Article Type / Makale Türü
Research Article / Araştırma Makalesi
\end{abstract}

\begin{abstract}
Keywords
Relationship Marketing, Perceived

Organizational Performance, Maritime Business
\end{abstract}

\begin{abstract}
Anahtar Kelimeler
İlişkisel Pazarlama, Kurumsal Performans

Algısı, Denizcilik İşletmesi
\end{abstract}

JEL Codes: M31, L25, M10

Submitted: $\quad 16 / 08 / 2021$

Accepted: $\quad 20 / 09 / 2021$ trade and its importance is increasing day by day. The maritime sector, which plays an important role in transportation, facilitates trade flow and transportation. The maritime sector is the core of international trade and the global economy. About $80 \%$ of world trade by volume and more than $70 \%$ by value is transported by sea (unctad.org/webflyer, 2020). For this reason, the current study tries to understand the relationship between relationship marketing (RM) in the maritime sector and employees' perceived organizational performance (POP). In globally competitive conditions, businesses need to operate in a customer-orientated manner in order to meet consumer needs and expectations and to gain a competitive advantage. In the marketing discipline, employees are expressed as internal customers and employee satisfaction is generally associated with internal customer satisfaction. Within management literature, this concept, which is identified as job satisfaction, can be considered as a complementary perspective for businesses to achieve success in terms of both disciplines. Therefore, employees who are satisfied with both their organization and their job would provide profitability to their businesses. This process is expressed by the "service- 
profit chain" model developed by Heskett et al. (1994). However, one of the striking issues in this model is that the importance of relationships is not taken into account. This situation brought the concept of RM to the agenda (Herington et al., 2006: 372). Because, the marketing discipline is involved in all areas of the social structure through relations (Erdoğan et al., 2011: 3). RM started to be discussed in the 1990s as a paradigm change against the inadequacy of the marketing mix (Çalışkan and Esmer, 2017: 204). Although the RM approach, which proposes emotional, economic and structural ties with the parties and adopts the formation of cooperation between them (Sin et al., 2002: 656), was first introduced by Berry in 1983 (Berry, 2002: 59), that does not seem to be a common view on what it actually is and what it covers. (Grönroos, 2017a: 218). In this context, it is stated that different definitions are made in different disciplines, but they see the relationship as an interaction tool between partners (Osobajo et al, 2021: 4). Berry (2002) defined RM as attracting, maintaining and developing customer relationships in multi-service organizations. RM is defined as all marketing activities aimed at maintaining and developing relationships (Morgan and Hunt, 1994: 34). RM, which is generally considered as an explanatory element for long-term relationships (Grönroos, 1996; Arl1, 2013), is expressed as ensuring exchange by fulfilling mutual promises (Osobajo et al, 2021: 4). According to Grönroos (2017b), if the processes of the service provider and the customer are combined in an interactive, collaborative and dialogue process, the firm can create value together with the customer. RM can also add value to businesses that will distinguish them from their competitors (Çalışkan and Esmer, 2017: 202), can establish a connection between employees, the organization and external customers, and increase the performance of employees (Wu et al., 2012: 438). While relationship quality can increase customer relationship performance (Çalışkan and Esmer, 2019: 381), unsuccessful relationships can cause negativity and undesirable results (Çalışkan, 2019: 196). Therefore, within the scope of RM, business philosophy can be seen as a corporate culture that puts the relationship between the parties at the center of strategic management thought (Sin et al., 2006: 408).

It is stated that the business philosophy, which starts with the production, adopts RM after the sales and marketing approach, it focuses on providing benefits with a long-term buyer-seller relationship from both sides (Sin et al., 2006: 408). Most researchers stated that RM contributes to improving organizational performance (Sin et al., 2005; Sin et al., 2006; Wu et al., 2012). Sin et al., (2005) states that a company that adopts RM can improve its performance and be sustainable as a result of long-term and mutually beneficial relationships. Businesses need to adopt a relationship marketing orientation (RMO) that will improve their performance (Sin et al., 2002: 656). In this context, Sin et al. (2005) proposed six dimensions as trust, bonding, communication, shared value, empathy and reciprocity as a solution to the operational problem of RM. In this sense, trust is an issue that draws attention in the relationship between employees, as in every field (Campbell et al. 2020: 32). Trust is defined as the level at which the parties feel to believe in the correctness of their words (Wu et al., 2012: 440). There are strong relationships between trust (Morgan and Hunt, 1994: 22), which is the most important component of RM, and the communication of employees in a workplace environment (Butler and Cantrell, 1994: 33). Effective communication flow in organizations improves the strong bond between employees and management and increases productivity (Sadia et al., 2016: 93). It includes developing customer loyalty with loyalty, love and a sense of belonging and indirectly belonging to the organization (Sin et al., 2006: 409). Effective communication, defined as the formal and informal sharing of information between parties, can resolve conflicts and regulate perceptions ( $\mathrm{Wu}$ et al., 2012: 440). Empathy can be expressed as thinking and seeing from the perspective of the other party, and shared value as having common beliefs of the parties (Morgan \& Hunt, 1994; Sin et al., 2006). Reciprocity, on the other hand, can be briefly explained by the equivalent benefit between the parties (Wu et al., 2012: 440).

In organizations, every stakeholder is important to the company. However, the understanding of customer orientation by consumers primarily requires a culture of relationship among employees (Amine et al. 2012: 72). Effective communication is vital to organizational performance. Therefore, not only managers but also their employees should be effective communicators. Employees' commitment to corporate values will greatly contribute to the long-term continuation of the 
organization's activities (Alkaya and Taştekin, 2021: 1386). In this case, managers have great responsibilities (Campbell et al. 2020: 39). The spirit of the organization and the community within it must be in harmony. This is closely related to the concept of commitment (Ridder, 2004: 20). However, the compatibility of employees may also be related to their personalities. It has been determined that there are positive and significant relationships between being extraverted, agreeable and trust (Yildiz and Kirmizbiber, 2020:494). In the context of "theory of reasoned action", which accepts that behaviours' are determined by intention, it is stated that personality traits have moderating effects on purchase intention (Torlak and Özkara, 2017: 90). A compatible or extroverted individual can welcome all the RM practices offered by the business (Çalışkan, 2019: 207). With the thought that successful internal relations are required for successful customer relations (Herington et al., 2006: 364), RMO in this research is handled as maintaining long-term relationships based on trust, close cooperation, empathy and communication among employees.

\section{Purpose and Hypothesis of the Research}

Researchers in the field of marketing and management have embraced the importance of the human factor. The marketing approach adopted by the owners/managers determines both their performance in strategic marketing planning and their relations with business stakeholders (Kılıçer et al., 2018, 87). It is stated that businesses that provide customer relations training to their employees and ensure their satisfaction are positively differentiated from those that do not practice this practice (Arac1 et al., 567). Employees, who have a great impact on the performance of organizations, provide competitive advantage to organizations as unique resources that competitors cannot imitate (Kanyurhi and Akonkva, 2016: 777). Customer relations is a concept that includes relations with external customers as well as internal customers within the organization. Organizations need to develop a culture of building relationships internally as well as externally in order to compete. Because good customer relationship is based on successful internal relationships (Herington et al., 2006: 364). In this context, the aim of the research is to determine the relationship between RMO and perceived organizational performance (POP) and to determine the effect of RMO dimensions on POP.

In the literature, it is seen that RM researches are generally conducted for external customers. For example, Keskin and Kurtuldu (2019) found that communication and service quality, which are among the dimensions of RM, have a significant impact on bank customer satisfaction. Y1lmaz (2016) found that RM activities have a positive effect on customers' intention to choose the same bank again. On the other hand, it has been determined that RM practices have an effect on the intention to reprefer and recommend in marina businesses (Arl 2013; Altunoğlu and Erbilgin, 2018). Shin et al. (2018) in their study on the maritime logistics industry determined that the trust factor as a relationship quality dimension is effective on the supply chain performance. Osobajo et al., (2021) claimed that trust factor among maritime supply chain stakeholders will positively affect supply chain performance. It was also noted the need to develop long-term successful relationship between the partners. Caliskan and Esmer (2020) state that ports can provide positive effects on customer loyalty, satisfaction and word of mouth by using social, structural and financial RM tactics.

Employees, customers, partners, suppliers and other stakeholders form a network of relationships. Although the stakeholders are not in direct contact with each other, they will affect each other more or less (Liljander, 2000, 162). There are strong relationships between trust and communication between employees, especially in a workplace environment (Butler and Cantrell, 1994: 33). RM approach proposes emotional, economic and structural ties with the interacted parties and adopts the cooperation approach between the parties. Therefore, businesses should adopt a RMO that will improve their performance (Sin et al., 2002: 656). Studies show that POP of employees can have significant effects on attitudes and behaviors (Perry-Smith and Blum, 2000; Carmeli et al., 2007). It is also stated that RMO is positively related to the marketing and financial performance of a business (Sin et al., 2006: 407). In this context, while cultivated communication and good relations bring productivity and success, negative communication in the working environment can prevent all this success. Accordingly, the following hypotheses are proposed: 
Ha: There is a positive and significant relationship between relationship marketing orientation and perceived organizational performance of employees.

$\mathrm{Hb}$ : Relationship marketing orientation has a positive effect on employees' perceptions of corporate performance.

\section{Method}

Questionnaire was used as a data collection tool in the research. To ensure the validity and reliability of the research, first of all, a literature review was made, and relevant resources were used in the development of the questionnaire. As a result of the literature review, for the POP scale, Choi and Yu, (2014) and Sin et al., (2006) studies were used for the RMO scale. The sample of the research consists of 274 employees of the maritime business in the Turkey office of an international maritime company operating with approximately 800 personnel. There were 20 questions in the questionnaire form. According to Tabachnik and Fidell (2007), the study $(n>50+8 m)$ complies with the minimum sample size criteria (Çelik and Özkara, 2017: 1233). Research data were collected between 01.03.2020 - 25.3.2020 by using an electronic questionnaire with convenience sampling method. The questionnaire form consists of two parts. In the first part of the questionnaire, it was prepared as a 5-point Likert Scale: 1: Strongly Disagree, 2: Disagree, 3: Neutral, 4: Agree, 5: Strongly Agree. These questions consist of statements that measure participants' RMO and POP. In the second part, questions prepared to determine demographic characteristics are listed. Frequency and percentage distributions were determined in the questions prepared for the demographic characteristics of the participants. The demographic characteristics of the participants in the study are shown in Table 1.

Table 1. Demographic Characteristics

\begin{tabular}{c|c|c|c|c|c}
\hline Gender & $\mathbf{N}$ & $\mathbf{0}$ & Marital status & $\mathbf{N}$ & $\mathbf{0}$ \\
Female & 54 & 19.7 & Married & 165 & 60.2 \\
Male & 220 & 80.3 & Single & 109 & 39.8 \\
Age & & & Education & & \\
$18-25$ & 18 & 6.6 & High school & 20 & 7.3 \\
$26-33$ & 77 & 28.2 & College & 204 & 74.5 \\
$34-41$ & 90 & 32.8 & Graduate & 50 & 18.2 \\
$42-49$ & 56 & 20.4 & Position & & \\
$50+$ & 33 & 12 & Executive & 68 & 24.8 \\
Experience (Years) & 165 & 60.2 & Technical Staff & 33 & 16.8 \\
$1-10$ & 46 & 16.8 & Office Clerk & 47 & 12 \\
$20+$ & 63 & 23 & Sales Person & 40 & 17.2 \\
& & Other & 40 & 14.6 \\
\end{tabular}

In Table 1, the majority of the participants in the research are men. However, it can be said that the distribution obtained in the research is in parallel with the ratio of female and male employees in the sector. In addition, $60.2 \%$ of the maritime sector employees participating in the research are married, 39.8\% are single, and the vast majority $(60.2 \%)$ have worked in the maritime sector for 1-10 years. The majority of the participants are university graduates with a rate of $74.5 \%$, followed by graduates with $18.2 \%$ and high school graduates with $7.3 \% .32 .8 \%$ of the participants are in the age group of $34-41,28.2 \%$ are in the age group of $26-33$, and $20.4 \%$ are in the age group of $42-49$. Furthermore, $24.8 \%$ of the participants work as managers, $17.2 \%$ as office clerks, $16.8 \%$ as specialists, $14.6 \%$ as sales personnel and other employees, and $12 \%$ as technical personnel. According to the demographic findings of the research, the majority of the participants are male and consist of university graduates. It is seen that approximately $80 \%$ of the research sample is in the age range of 26-49, mostly married and has 1-10 years of work experience, and consists of the crew who hold various positions. 


\section{Analysis of Data}

\subsection{Reliability and Validity}

The data obtained within the scope of the research was analyzed with the IBM SPSS Statistics 24 package program. Reliability analysis was applied to measure the reliability of the questionnaire questions. As a result of the reliability analysis applied to 26 questions created with the Likert scale in the questionnaire, the General Alpha reliability coefficient (Cronbach's Alpha) was found to be 0.935. Within the scope of the research, the current RMO scale consists of six dimensions (trust, bonding, communication, shared value, empathy and reciprocity) and a total of 22 questions, and the scale of POP consists of four questions. In order to ensure the validity of the scales, factor analysis was applied using the varimax method. As a result of the analysis, factor values of 0.50 and above were taken into account, and items below 0.50 were excluded from the analysis. As a result of the factor analysis being performed again, relational marketing orientation was determined as three dimensions. Factor analysis results are shown in Table 2.

Table 2. Result of Factor Analysis

\begin{tabular}{|c|c|c|c|c|}
\hline Factors & $\begin{array}{c}\text { Factor } \\
\text { Load }\end{array}$ & Eigenvalue & $\begin{array}{c}\% \text { of } \\
\text { Variance }\end{array}$ & $\begin{array}{l}\text { Cronbach's } \\
\text { Alpha }\end{array}$ \\
\hline \multicolumn{5}{|l|}{ Empathy-based communication } \\
\hline We communicate and express our views to each other & 0.804 & & & \\
\hline We are in constant contact & 0.770 & & & \\
\hline We work in close cooperation & 0.743 & & & \\
\hline We can express our displeasure at each other & 0.725 & & & \\
\hline We care about each other's feelings & 0.710 & 9.145 & 45.723 & 0.921 \\
\hline We can communicate honestly & 0.705 & & & \\
\hline I try to build long-term relationships & 0.648 & & & \\
\hline We know how each other feels & 0.623 & & & \\
\hline We respect each other's values & & & & \\
\hline \multicolumn{5}{|l|}{ Shared Value } \\
\hline We share the same worldview & 0.870 & & & \\
\hline We share the same view on many issues & 0.834 & 2.142 & 10.709 & 0.925 \\
\hline We share the same feelings towards our environment & 0.820 & & & \\
\hline We share the same values & 0.818 & & & \\
\hline Trust & & & & \\
\hline We trust each other & 0.829 & 1197 & 5083 & 0907 \\
\hline We trust each other in important matters & 0.811 & 1.197 & 5.983 & 0.901 \\
\hline My organization trusts its employees & 0.802 & & & \\
\hline Perceived Organizational Performance & & & & \\
\hline My company has a high production-profitability ratio & 0.850 & & & \\
\hline It has a competitive advantage at market value & 0.726 & 1.649 & 8.247 & 0.803 \\
\hline Savings and efficiency are very high & 0.714 & & & \\
\hline It has a competitive advantage in brand development. & 0.710 & & & \\
\hline \multicolumn{2}{|l|}{ Kaiser Meyer Olkin (KMO) $\quad 0.908$} & Total & Variance \% & 70.663 \\
\hline \multicolumn{5}{|l|}{$\begin{array}{ll}\text { Bartlett's Test of Sphericity } & \text { Approx. Chi-Square: } 3954.912 \\
& \text { df : } 190 \text { Sig: } 0.000\end{array}$} \\
\hline \multicolumn{5}{|c|}{$\begin{array}{l}\text { As seen in Table } 2 \text {, four significant factors were formed, the first three factors being the RMC } \\
\text { dimension, which explained } 70,663 \% \text { of the total variance. Therefore, in our study, the dimension } \\
\text { that make up the RMO variable were determined as empathy-based communication (named } \\
\text { depending on the content), trust and shared value. With the Bartlett test of sphericity, it wa } \\
\text { determined that there was a sufficient level of correlation between the variables for factor analysi } \\
\text { ( } \mathrm{p}=0.00<0.05) \text {. Kaiser-Meyer-Olkin }(\mathrm{KMO}) \text { value of } 0.90 \text { and above is accepted as marvellous (Kaise } \\
\text { 1974: } 35 \text { ). Since the KMO sample measurement adequacy is } 0.908 \text {, it can be said that the variable } \\
\text { are suitable for factor analysis. }\end{array}$} \\
\hline
\end{tabular}




\subsection{Hypothesis Tests}

Within the scope of the research, the relations and the direction of the relations between empathy-based communication, shared value and trust, which are the dimensions of RMO, and the POP were examined by correlation analysis ( $\mathrm{Ha})$. The $\mathrm{Hb}$ research hypothesis, which includes the determination of the effects of RMO dimensions, which are independent variables, on the POP was tested with multiple regression analysis.

\subsubsection{Correlation Analysis}

Correlation analysis was performed to measure the relationships between the variables and the results are presented in Table 3.

Table 3. Result of Correlation Analysis

\begin{tabular}{|c|c|c|c|c|c|c|}
\hline Average & $\begin{array}{l}\text { Standard } \\
\text { deviation }\end{array}$ & & $\begin{array}{l}\text { Empathy-based } \\
\text { Communication }\end{array}$ & $\begin{array}{l}\text { Shared } \\
\text { Value }\end{array}$ & Trust & $\begin{array}{c}\text { Perceived } \\
\text { Organizational } \\
\text { Performance }\end{array}$ \\
\hline 3.99 & .666 & $\begin{array}{l}\text { Empathy-based } \\
\text { communication }\end{array}$ & 1 & 0.619 & 0.585 & 0.424 \\
\hline 3.36 & .779 & $\begin{array}{l}\text { Shared } \\
\text { Value }\end{array}$ & & 1 & 0.430 & 0.347 \\
\hline 3.77 & .861 & Trust & & & 1 & 0.500 \\
\hline 3.94 & .677 & $\begin{array}{c}\text { Perceived } \\
\text { Organizational } \\
\text { Performance } \\
\end{array}$ & & & & 1 \\
\hline
\end{tabular}

Correlation is significant at the 0.01 level (2-tailed).

As a result of the correlation analysis, the independent variables that were found to be the most effective on the POP were trust, empathy-based communication and shared value variables, respectively. There is a significant positive relationship at the $1 \%$ level between the variables. Therefore, it can be said that there is a positive relationship between RMO and POP. In summary, empathy-based communication and value sharing, especially trust among employees in the organization, are positively related to their POP. Therefore, the Ha hypothesis was supported.

\subsubsection{Regression Analysis}

As a result of the correlation analysis, multiple regression analysis can be performed because of the clear relationship between the POP and the variables of trust, empathy-based communication, and shared value (Alkaya et al., 2016). Regression analysis was applied while there were empathybased communication, shared value and trust variables in the model. Regression analysis was applied while there was empathy-based communication, shared value and trust variables in the model. Analysis results are shown in Table 4 and Table 5.

Table 4. Result of Regression Analysis

\begin{tabular}{|c|c|c|c|c|c|c|c|c|c|}
\hline \multirow{2}{*}{ Model } & \multicolumn{2}{|c|}{$\begin{array}{c}\text { Unstandardized } \\
\text { Coefficients }\end{array}$} & \multirow{2}{*}{$\begin{array}{c}\begin{array}{c}\text { Standardized } \\
\text { Coefficients }\end{array} \\
\text { Beta }\end{array}$} & \multicolumn{6}{|c|}{$\begin{array}{l}\text { Collinearity } \\
\text { Statistics }\end{array}$} \\
\hline & $\beta$ & $\begin{array}{l}\text { Std. } \\
\text { Error }\end{array}$ & & $\mathrm{t}$ & $\mathrm{p}$ & Tolerance & VIF & F & $\mathrm{p}$ \\
\hline Constant & 1.994 & .216 & & 9.254 & .000 & & & & \\
\hline Shared Value & .074 & .051 & .097 & 1.463 & .145 & .610 & 1.639 & & \\
\hline $\begin{array}{l}\text { Empathy-based } \\
\text { Communication }\end{array}$ & .149 & .075 & .147 & 1.993 & .047 & .492 & 2.033 & 35.348 & 0.00 \\
\hline Trust & .293 & .050 & .373 & 5.825 & .000 & .650 & 1.538 & & \\
\hline
\end{tabular}

Dependent Variable: Perceived Organizational Performance

Table 5. Regression Model Summary

\begin{tabular}{cccccc}
\hline Model & $\mathrm{R}$ & $\mathrm{R}^{2}$ & Adjusted $\mathrm{R}^{2}$ & Std. Error of the Estimate & Durbin-Watson \\
\hline 1 & 0.531 & 0.282 & 0.274 & 0.57654 & 1.739 \\
\hline
\end{tabular}


In Table 5, it is seen that the value perception, empathy-based communication, and trust factors in the regression model explain $27.4 \%$ of the total variance. In addition, since the Durbin Watson value is 1.739, it can be assumed that there is no autocorrelation (Kalayc1, 2010: 267). According to the VIF values in Table 4, there is no multicollinearity problem between the variables. In addition, the model was found to be significant since $p=0.00<0.05$. However, the fact that the shared value $p$ corresponding to the $\beta$ coefficients is not significant, suggests that there is a multicollinearity problem between the independent variables. For this reason, the variable that caused the multicollinearity problem was removed from the model and a regression model was created with the stepwise method, and the results are shown in Table 6 and Table 7.

Table 6. Summary of the Stepwise Regression Model

\begin{tabular}{cccccc}
\hline Model & $\mathrm{R}$ & $\mathrm{R}^{2}$ & Adjusted $\mathrm{R}^{2}$ & Std. Error of the Estimate & Durbin-Watson \\
\hline 1 & 0.500 & 0.250 & 0.247 & 0.58713 & \\
2 & 0.526 & 0.276 & 0.271 & 0.57776 & 1.746 \\
\hline
\end{tabular}

Table 7. Result of Stepwise Regression Analysis

\begin{tabular}{|c|c|c|c|c|c|c|c|c|c|}
\hline Model & \multicolumn{2}{|c|}{$\begin{array}{c}\text { Unstandardized } \\
\text { Coefficients }\end{array}$} & $\begin{array}{c}\text { Standardized } \\
\text { Coefficients }\end{array}$ & \multicolumn{6}{|c|}{$\begin{array}{l}\text { Collinearity } \\
\text { Statistics }\end{array}$} \\
\hline 1 & $\beta$ & $\begin{array}{l}\text { Std. } \\
\text { Error }\end{array}$ & Beta & $\mathrm{t}$ & $\mathrm{p}$ & Tolerance & VIF & $\mathrm{F}$ & $\mathrm{p}$ \\
\hline Constant & 2.463 & .160 & & 15.432 & .000 & & & 90601 & 0.00 \\
\hline Trust & .393 & .041 & .500 & 9.518 & .000 & 1.000 & 1.000 & 30.001 & 0.00 \\
\hline 2 & \multicolumn{9}{|c|}{ Dependent Variable: Perceived Organizational Performance } \\
\hline Constant & 1.996 & .216 & & 9.242 & .000 & & & & \\
\hline Trust & .300 & .050 & .382 & 6.001 & .000 & .657 & 1.521 & 51.734 & 0.00 \\
\hline $\begin{array}{l}\text { Empathy-based } \\
\text { Communication }\end{array}$ & .204 & .065 & .201 & 3.147 & .002 & 657 & 1.521 & & \\
\hline
\end{tabular}

As a result of the stepwise regression analysis, model 1, which includes the trust variable that is most associated with the POP, and then model 2, which also includes the empathy-based communication variable, was created. Therefore, the results of stepwise regression analysis will be interpreted according to model 2. In Table 6, independent variables explain $27.1 \%$ of the total variance in the model. Durbin Watson value is 1.746 and it can be said that there is no autocorrelation in the stepwise regression analysis. In addition, when the importance levels of VIF and partial $t$ values $(\mathrm{p}<=0.05)$ are considered, it can be suggested that the multicollinearity problem has been resolved. It is seen that the independent variables in the model are statistically significant $(\mathrm{p}<=0.05)$. In Table 7 , it is seen that the independent variables in model 2 are trust $(\beta=0.300)$ and empathy-based communication $(\beta=0.204)$, respectively, according to the effect coefficients on the perception of corporate performance.

Regression equation: $P O P=1.996+0.300$ (Trust) +0.204 (Empathy-based communication)

Within the scope of the research, the $\mathrm{Hb}$ hypothesis was rejected because the value perception variable, which is one of the identified RMO dimensions, could not be found to have an influence the POP along with other variables. Only trust and empathy-based communication factor together have an effect on the POP.

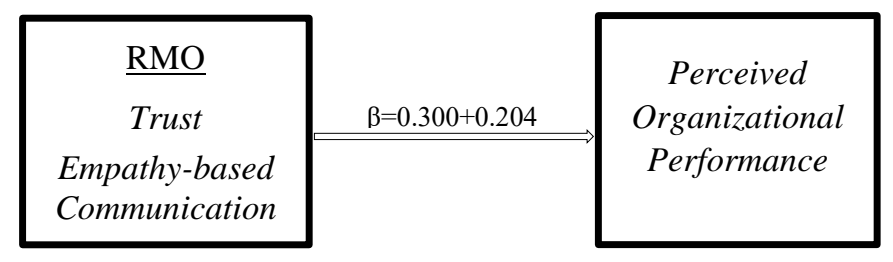

Figure 1: Result Model 


\section{Conclusion}

Being successful in the intense business and competitive environment brought about by globalization requires a company to be customer-oriented. Undoubtedly, the most fundamental element of corporate success and performance is employees. The marketing and management discipline frequently states in the literature that employees have a great impact on the performance of institutions and their strategic importance. Employees' relationships in their organizations are important. In particular, the trust factor is the basis of everything, including the communication of employees with each other. RM, which is a strategic concept for businesses to gain competitive advantage in the market and adopts the cooperation approach between the parties, ensures the establishment and continuity of long-term relationships. Sustainable positive relationships between internal customers, which are the most fundamental resource of organizations, and their POP can be the driver of the approach towards external customers. For this reason, the study examined the relationship between RMO and employees' POP.

The findings obtained within the scope of the research showed that there is a positive and significant relationship between the RMO and the POP of the employees. As a result of the regression analysis, it was concluded that the trust and empathy-based communication were effective on the POP of the employees. As a result of the RM approach, it can be said that empathybased communication, especially trust among employees, is effective on POP. Cooperation and solidarity of employees, which are the most fundamental factors for organizations to be sustainable and increase their market shares, are important. Organizations' adopting a RM approach can help their productivity. For this reason, organizations can adopt a RMO towards employees, which is the most basic element that will contribute to their performance and help increase their competitiveness in the market. In this context, the study was carried out in the maritime business in the Turkey office of an operating international maritime company. In addition, the quantitative method was adopted in the study. It would be beneficial to carry out future studies for other sectors with different methods and approaches.

\section{References}

Alkaya, A. \& Taştekin İ. (2021). Kamu hizmeti motivasyonuna örgütsel bağllığın etkisi: Nevşehir ili lise öğretmenleri uygulaması. Electronic Journal of Social Sciences, 79(20), 1385-1404.

Alkaya, A., Çoban, S., Tehci, A. \& Ersoy, Y. (2016). Çevresel Duyarliliğin Yeşil Ürün Satin Alma Davranişina Etkisi: Ordu Üniversitesi Örneği. Erciyes Üniversitesi İktisadi ve İdari Bilimler Fakültesi Dergisi, (47), 121-134.

Altunoğlu, A. E., \& Erbilgin, R. (2018). Marina işletmeciliğinde ilişkisel pazarlama uygulamalarının sadakat ve tavsiye etme üzerindeki etkisi. In 3rd Eurasian Conference on Language and Social Sciences, June, 27(29), 319-334.

Amine, M. E. A., Chakor, A. \& Alaoui, A. M. (2012). Ethics, relationship marketing and corporate performance: Theoretical analysis through the mediating variables. International Business Research, 5(8), 68.

Araci, Ü. E., Bulut, Z. A., Onaran, B., \& Koçak, N. (2014). Fark Yaratan Uygulamalar Perspektifinden Seyahat Acentelerinde Iliskisel Pazarlama Faaliyetlerini Anlama. Ege Akademik Bakis, 14(4), 559.

Arlı, E. (2013). Marina işletmeciliğinde ilişkisel pazarlama uygulamalarının tekrar satın alma niyeti, tavsiye etme niyeti ve memnuniyet üzerindeki etkisi. Anadolu University Journal of Social Sciences, 13(1), 61-76.

Berry, L. L. (2002). Relationship marketing of services perspectives from 1983 and 2000. Journal of relationship marketing, 1(1), 59-77.

Butler Jr, J. K. \& Cantrell, R. S. (1994). Communication factors and trust: An exploratory study. Psychological reports, 74(1), 33-34.

Caliskan, A. \& Esmer, S. (2017). Port industry related relationship marketing applications. Journal of ETA Maritime Science, 5(2), 202-215.

Caliskan, A. (2019). Applying the right relationship marketing strategy through big five personality traits. Journal of Relationship Marketing, 18(3), 196-215. 
Caliskan, A., \& Esmer, S. (2019). Does it really worth investing in relationship marketing for a port business?. Case Studies on Transport Policy, 7(2), 375-383.

Caliskan, A., \& Esmer, S. (2020). An assessment of port and shipping line relationships: the value of relationship marketing. Maritime Policy \& Management, 47(2), 240-257.

Campbell, S., Campbell-Phillips, S. \& Phillips, D. (2020). Lack of Communication between Management and Employees. SIASAT, 5(3), 32-39.

Carmeli, A., Gilat, G. \& Waldman, D. A. (2007). The role of perceived organizational performance in organizational identification, adjustment and job performance. Journal of Management Studies, 44(6), 972-992.

Choi, Y. \& Yu, Y. (2014). The influence of perceived corporate sustainability practices on employees and organizational performance. Sustainability, 6(1), 348-364.

Çelik, Z., \& Özkara, B. Y. (2017). Kişisel Motivasyon Faktörlerinin Olumsuz Elektronik Ağızdan Ağıza İletişim Yapma Niyeti Üzerindeki Etkisi. Itobiad: Journal of the Human $\mathcal{E}$ Social Science Researches, 6(2).

De Ridder, J. A. (2004). Organisational communication and supportive employees. Human Resource Management Journal, 14(3), 20-30.

Erdoğan, B. Z., Tiltay, M. A. \& Kimzan, H. S. (2011). Pazarlama Teorisi'nin Felsefi Temelleri: Değişim mi, İlişki mi?. Tüketici ve Tüketim Araştırmaları Dergisi, 3(1), 1-28.

Grönroos, C. (1996). Relationship Marketing: Strategic and Tactical Implications, Management Decision, 34(3), s.5-14.

Grönroos, C. (2017a). Relationship marketing readiness: theoretical background and measurement directions. Journal of Services Marketing. 31(3), 218-225.

Grönroos, C. (2017b). On value and value creation in service: a management perspective. Journal of Creating Value, 3(2), 125-141.

Herington, C., Johnson, L. W. \& Scott, D. (2006). Internal relationships: Linking practitioner literature and relationship marketing theory. European Business Review, 18(5), 364-381.

Heskett, J. L., Jones, T. O., Loveman, G. W., Sasser, W. E. \& Schlesinger, L. A. (1994). Putting the service-profit chain to work. Harvard Business Review, 72(2), 164-174.

Kaiser, H. F. (1974). An index of factorial simplicity. Psychometrika, 39(1), 31-36.

Kalaycı, Ş. (2010). Faktör Analizi. iç. Şeref Kalaycı (Ed.), SPSS Uygulamalı Çok Değişkenli İstatistik Teknikleri, Beşinci Baskı, An-kara: Asil Yayın Dağıtım, 321-331.

Kanyurhi, E. B. \& Akonkwa, D. B. M. (2016). Internal marketing, employee job satisfaction, and perceived organizational performance in microfinance institutions. International Journal of Bank Marketing, 34(5), 773-796.

Keskin, H. D., \& Kurtuldu, H. S. (2019). İlişkisel pazarlamanın müşteri memnuniyeti üzerindeki etkisi: Banka müşterilerine yönelik bir uygulama. Global Journal of Economics and Business Studies, 8(16), 111-121.

Kılıçer, T., Boyraz, E., Gürses, F., \& Gülmez, Y. S. (2018). KOBİlerin stratejik pazarlama performansı ve ilişkisel pazarlama becerisinde işletme sahip ve yöneticilerinin rolü. Pazarlama İçgörüsü Üzerine Çalışmalar, 2(2), 69-89., 2(2), 69-89.

Liljander, V. (2000). The importance of internal relationship marketing for external relationship success. In Relationship Marketing (pp. 161-192). Springer, Berlin, Heidelberg.

Morgan, R. M. \& Hunt, S. D. (1994). The commitment-trust theory of relationship marketing. Journal of Marketing, 58(3), 20-38.

Osobajo, O. A., Koliousis, I. \& McLaughlin, H. (2021). Making sense of maritime supply chain: a relationship marketing approach. Journal of Shipping and Trade, 6(1), 1-17.

Perry-Smith, J. E., \& Blum, T. C. (2000). Work-family human resource bundles and perceived organizational performance. Academy of Management Journal, 43(6), 1107-1117.

Sadia, A., Salleh, B. M., Kadir, Z. A. \& Sanif, S. (2016). The relationship between organizational communication and employees productivity with new dimensions of effective communication flow. Journal of Business and Social Review in Emerging Economies, 2(2), 93-100. 
Shin, Y., Thai, V., \& Yuen, K. F. (2018). The impact of supply chain relationship quality on performance in the maritime logistics industry in light of firm characteristics. The International Journal of Logistics Management. 29(3), 1077-1097.

Sin, L. Y. M., Tse, A. C. B., Yau, O. H. M., Lee, J. S. Y. \& Chow, R. (2002). The effect of relationship marketing orientation on business performance in a service-oriented economy. Journal of Services Marketing, 16(7), 656-676.

Sin, L. Y., Tse, A. C., Chan, H., Heung, V. C. \& Yim, F. H. (2006). The effects of relationship marketing orientation on business performance in the hotel industry. Journal of Hospitality $\mathcal{E}$ Tourism Research, 30(4), 407-426.

Sin, L. Y., Tse, A. C., Yau, O. H., Chow, R. P. \& Lee, J. S. (2005). Market orientation, relationship marketing orientation, and business performance: The moderating effects of economic ideology and industry type. Journal of International Marketing, 13(1), 36-57.

Tabachnick, B. G. \& Fidell, L. S. (2007). Using Multivariate Statistics, $5^{\text {th }}$ Edition, Boston, Pearson Education.

Torlak, Ö. \& Özkara, B. Y. (2017). Sebepli Eylem Teorisi Bağlamında, Kişilik Özelliklerinin İnternet Üzerinden Satın Alma Davranışı Üzerindeki Rolü. Pazarlama Teorisi ve Uygulamaları Dergisi, 3(1), 77-94.

UNCTAD. 2020. Review of Maritime Transport 2020. United Nations Conference on Trade and Development Publication, Geneva.

Wu, W. Y., Tsai, C. C. \& Fu, C. S. (2013). The relationships among internal marketing, job satisfaction, relationship marketing, customer orientation, and organizational performance: An empirical study of TFT-LCD companies in Taiwan. Human Factors and Ergonomics in Manufacturing $\mathcal{E}$ Service Industries, 23(5), 436-449.

Yıldız S. \& Kırmızıbiber A. (2020). Kişilik özellikleri ile güven ve risk arasındaki ilişki: e-ticaret müşterileri üzerine bir uygulama. Gümüşhane Üniversitesi Sosyal Bilimler Enstitüsü Elektronik Dergisi, 11(2), 494-507.

Yılmaz, Ö. (2016). Bankacılıkta ilişkisel pazarlama faaliyetlerinin, tekrar satın alma niyeti üzerine etkisinde ilişkisel kalite algısının aracılık rolü üzerine bir araştırma. Business $\mathcal{E}$ Management Studies: An International Journal, 4(2), 142. 